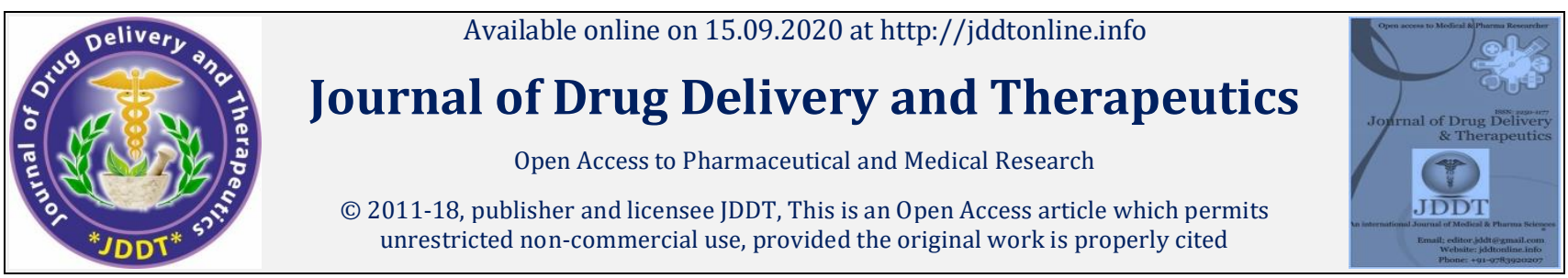

Open $\odot$ Access

Research Article

\title{
Herbal Remedies Used to Treat Skin Disorders in Arasankulam Region of Thoothukudi District in Tamil Nadu, India
}

\author{
Sundari A*, Jayakumararaj R \\ Department of Botany, Government Arts College, Melur, Madurai - 625 106. Tamil Nadu, India
}

\begin{abstract}
As lacking in attention given to the ethnomedicinal plants to be used for the treatment of skin diseases in many areas, an ethnomedicinal study was carried out to enumerate the traditional uses followed to treat skin diseases among the people living in Arasankulam and Kottarakurichi villages located in Thoothukudi district of Tamil Nadu. The medicinal uses of 24 species belonging to 20 families were reported from the study area. Euphorbiaceae was noted as largest families comprising of 3 species each. Herbs (50.0\%) were found more in number than other life forms of plants. Leaves (50.0\%) were the mostly used plant part to prepare the medicine and paste (61.54\%) was the dominant mode to treat the skin ailments. By this research work, it was also noted that a total of 6 plants were used to heal wound, 4 plants for the treatment of cut, 3 plants each to cure boil and eczema, 2 plants to treat heel crack and 1 plant each for abrasion, chicken pox, dandruff, itch, leprosy, lip crack, scabies, skin allergy, small pox and tumor. Further studies on phytochemical and pharmacological aspects of these plants will contribute new dimensions to these medicinal plants.
\end{abstract}

Keywords: Medicinal plants, Skin diseases, Arasankulam region, Thoothukudi district, Tamil Nadu.

Article Info: Received 11 July 2020; Review Completed 14 August 2020; Accepted 19 August 2020; Available online 15 September 2020

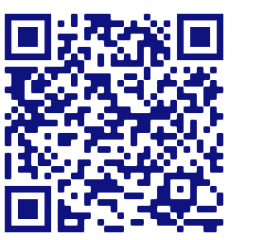

\section{Cite this article as:}

Sundari A, Jayakumararaj R, Herbal Remedies Used to Treat Skin Disorders in Arasankulam Region of Thoothukudi District in Tamil Nadu, India, Journal of Drug Delivery and Therapeutics. 2020; 10(5):33-38

http://dx.doi.org/10.22270/jddt.v10i5.4277

A. Sundari, Research Scholar, Department of Botany, Government Arts College, Melur, Madurai - 625 106. Tamil Nadu, India

\section{INTRODUCTION}

Skin diseases occur worldwide and account to nearly $34 \%$ of all occupational diseases reported. They affect people of all ages from childhood to ageing. Although mortality rates due to skin diseases are relatively low, they influence significantly on the quality of life and are often persistent and are difficult to treat 1 .

Traditional medicinal plant resources have been found to play a vital role in managing skin disorders. They have been employed by the various ethnic people in the treatment of skin ailments in many countries around the world where they contribute significantly in the primary health care of the population ${ }^{2-7}$.

Sequel researches on other traditional uses of medicinal plants have been given sufficient attention, but still lacking much more attention to the ethnobotanical plants to be used for the treatment of skin diseases especially in remote rural areas. Hence, the present study was aimed to document the ethnomedicinal knowledge on plants used in the treatment of skin disorders by the rural people dwelling in Arasankulam region of Thoothukudi district in Tamil Nadu.

\section{MATERIALS AND METHODS}

\subsection{The study sites}

Two villages namely, Arasankulam and Kottarakurichi were selected to conduct the ethnomedicinal survey. They are belonging to Srivaikuntam taluk of Thoothukudi district in Tamil Nadu. Geographically, Arasankulam is lying between $77.5576^{\circ}$ E longitude and 8.7087ㅇ $\mathrm{N}$ latitude, and Kottarakurichi between 78.0205을 E longitude and 8.6557ㅇ N latitude. The temperature of the study area is about $16-40^{\circ}$ $\mathrm{C}$ and annual rainfall reaches $850 \mathrm{~mm}$. Maximum landmass of both the study sites is covered with agricultural lands.

\subsection{Methodology}

An ethnobotanical survey at Arasankulam and Kottarakurichi villages was carried out from January to February, 2020. The informations on plants used as traditional medicine against various skin diseases were collected through interactions with local inhabitants included medical practitioners. The medicinal property of plant under study was confirmed by at least 4 informants. A total 11 peoples were interviewed during this study and out of 11,7 persons were men and 4 were women. Interviews 
were conducted in Tamil language and the data were transformed into English. The plants were botanically identified by using regional floras 8,9 .

\section{RESULTS AND DISCUSSION}

A total of 11 informants include 7 male (63.64\%) and 4 female $(36.36 \%)$ were interviewed on their knowledge of medicinal plants used to treat skin disorders in the study area. Among them, 7 respondents were belonging to Arasankulam village and 4 to Kottarakurichi village. All the respondents were grouped into three age categories viz., 20
40 years, 41-60 years and above 60 years and most of them (6 informants, $54.54 \%$ ) were in the category of $41-60$ years. The level of education revealed that $54.54 \%$ were educated and about $45.46 \%$ of the respondents have no formal education. In related to occupation, each of 5 informants were being as farmers and agricultural laborers respectively (Table 1). By this ethnomedicinal survey, it has been found that the male informants not only practice local traditional medicinal treatment regimens, but also have good knowledge about medicinal plants than female informants.

Table 1: Demographic data of informants

\begin{tabular}{|c|c|c|c|}
\hline \multirow{2}{*}{ Basic characteristics } & \multicolumn{3}{|c|}{ Number (percent distribution) } \\
\hline & Male & Female & Total informants \\
\hline \multicolumn{4}{|l|}{ Gender } \\
\hline Male/Female & $7(63.64)$ & $4(36.36)$ & $11(100.0)$ \\
\hline \multicolumn{4}{|l|}{ Name of village } \\
\hline Arasankulam & $5(71.42)$ & $2(50.0)$ & $7(63.64)$ \\
\hline Kottarakurichi & $2(28.58)$ & $2(50.0)$ & $4(36.36)$ \\
\hline \multicolumn{4}{|l|}{ Current age } \\
\hline $21-40$ years & $1(14.28)$ & $1(25.0)$ & $2(18.18)$ \\
\hline $41-60$ years & $4(57.14)$ & $2(50.0)$ & $6(54.54)$ \\
\hline Above 61 years & $2(28.58)$ & $1(25.0)$ & $3(27.28)$ \\
\hline \multicolumn{4}{|l|}{ Educational status } \\
\hline Literate & $5(71.42)$ & $1(25.0)$ & $6(54.54)$ \\
\hline Illiterate & $2(28.58)$ & $3(75.0)$ & $5(45.46)$ \\
\hline \multicolumn{4}{|l|}{ Occupation } \\
\hline Farmer & $4(57.14)$ & $1(25.0)$ & $5(45.46)$ \\
\hline Agri. Labourer & $2(28.58)$ & $3(75.0)$ & $5(45.46)$ \\
\hline Govt. Employee & $1(14.28)$ & 0 & $1(9.08)$ \\
\hline
\end{tabular}

Totally 24 plant species used for the treatment of 16 different skin disorders were recorded in the present survey (Table 2). These disorders include abrasion, boil, burn, chicken pox, cut, dandruff, eczema, heel crack, itch, leprosy, lip crack, scabies, skin allergy, small pox, tumor and wound. The 24 plant species belongs to 20 families, with Euphorbiaceae (3 species) being the most represented family, followed by Capparidaceae and Mimosaceae (2 species each) and the remaining 17 families were reported with one species each (Fig 1). In case of habits of the plants recorded, herbs were found maximum (12 nos., 50.0\%) than trees (8 nos., $33.34 \%$ ), shrubs (2 nos., 8.33\%), and climbers (2 nos., 8.33\%) (Fig 2). 
Table 2: List of medicinal plants used for skin disorders in Arasankulam region

\begin{tabular}{|c|c|c|c|c|}
\hline Botanical name & Family & Vernacular name & Habit & Medicinal use(s) \\
\hline $\begin{array}{l}\text { Acacia leucophloea (Roxb.) } \\
\text { Willd. }\end{array}$ & Mimosaceae & Velvaelam & Tree & $\begin{array}{l}\text { Stem bark paste is mixed with turmeric } \\
\text { powder and applied on cut and wound }\end{array}$ \\
\hline \multirow[t]{2}{*}{ Acalypha indica $\mathrm{L}}$. & \multirow[t]{2}{*}{ Euphorbiaceae } & \multirow[t]{2}{*}{ Kuppaimaeni } & \multirow[t]{2}{*}{ Herb } & Leaf juice is poured to heal abrasion \\
\hline & & & & $\begin{array}{l}\text { Paste prepared from aerial parts is } \\
\text { applied to treat scabies }\end{array}$ \\
\hline Aegle marmelos Corr. & Rutaceae & Vilvam & Tree & Leaf paste is applied to treat skin burn \\
\hline $\begin{array}{l}\text { Aristolochia bracteolata } \\
\text { Lam. }\end{array}$ & Aristolochiaceae & Aaduthinnaappaalai & Climber & $\begin{array}{l}\text { Leaf paste is applied on head before } \\
\text { bathing to get relieve from dandruff }\end{array}$ \\
\hline \multirow[t]{2}{*}{ Azadirachta indica A.Juss. } & \multirow[t]{2}{*}{ Meliaceae } & \multirow[t]{2}{*}{ Vaembu } & \multirow[t]{2}{*}{ Tree } & Leaf paste is applied to cure itch. \\
\hline & & & & $\begin{array}{l}\text { Leaf paste along with turmeric powder is } \\
\text { applied topically on the body to treat } \\
\text { small pox and chicken pox }\end{array}$ \\
\hline Boerhaavia diffusa $\mathrm{L}$. & Nyctaginaceae & Chaaranathi & Herb & $\begin{array}{l}\text { Root extract is applied to cure skin } \\
\text { allergy }\end{array}$ \\
\hline $\begin{array}{l}\text { Cadaba fruticosa (L.) } \\
\text { Druce. }\end{array}$ & Capparidaceae & Vizhuthi & Shrub & $\begin{array}{l}\text { Stem bark paste is applied on boil and } \\
\text { cut }\end{array}$ \\
\hline Catharanthus roseus Murr. & Apocynaceae & Nithyakalyaani & Herb & Root paste is applied to treat eczema \\
\hline Cleome viscosa $\mathrm{L}$. & Capparidaceae & Naaikadugu & Herb & Leaf juice is applied to cure eczema \\
\hline Cocos nucifera $\mathrm{L}$ & Arecaceae & Thennai & Tree & $\begin{array}{l}\text { Oil extracted from the mature fruit flesh } \\
\text { is used to treat cut and wound }\end{array}$ \\
\hline $\begin{array}{l}\text { Croton bonplandianum } \\
\text { Baill. }\end{array}$ & Euphorbiaceae & Vaenappoondu & Herb & Leaf extract is poured on cut and wound \\
\hline Delonix elata (L.) Gamble & Caesalpiniaceae & Perungondrai & Tree & Flower paste is applied to cure eczema \\
\hline Euphorbia hirta L. & Euphorbiaceae & Ammaanpacharishi & Herb & Diluted latex applied to treat lip crack \\
\hline Ficus benghalensis $\mathrm{L}$. & Moraceae & Aalamaram & Tree & $\begin{array}{l}\text { Stem latex is applied topically to cure } \\
\text { heal heel crack }\end{array}$ \\
\hline Heliotropium indicum L. & Boraginaceae & Thealkodukku & Herb & Leaf paste is applied to treat wound \\
\hline $\begin{array}{l}\text { Hemidesmus indicus (L.) } \\
\text { R.Br. }\end{array}$ & Asclepiadaceae & Nannaari & Climber & Root paste is applied to cure skin burn \\
\hline Justicia adathoda $\mathrm{L}$. & Acanthaceae & Adaathodai & Shrub & Leaf paste is applied for tumor \\
\hline Mangifera indica $\mathrm{L}$. & Anacardiaceae & Maa & Tree & $\begin{array}{l}\text { Latex obtained from leaf is applied to } \\
\text { heel crack }\end{array}$ \\
\hline Mimosa pudica L. & Mimosaceae & Thottaalsinungi & Herb & $\begin{array}{l}\text { Leaf paste is applied to treat burn and } \\
\text { wound }\end{array}$ \\
\hline Musa paradisiaca $\mathrm{L}$. & Musaceae & Vaazhai & Tree & $\begin{array}{l}\text { Exudate obtained from inner stem pour } \\
\text { burn }\end{array}$ \\
\hline Phyla nodiflora (L.) Greene & Verbenaceae & Poduthalai & Herb & Whole plant extract is pour to treat boil \\
\hline Plumbago zeylanica L. & Plumbaginaceae & Chithiramoolam & Herb & $\begin{array}{l}\text { Entire plant paste is applied to cure } \\
\text { leprosy }\end{array}$ \\
\hline Sida acuta Burm.f. & Malvaceae & Arivalmanaipoondu & Herb & Leaf paste is applied to heal wound \\
\hline Tridax procumbens $\mathrm{L}$. & Asteraceae & Vettukkaayathalai & Herb & Leaf paste is applied on boil \\
\hline
\end{tabular}




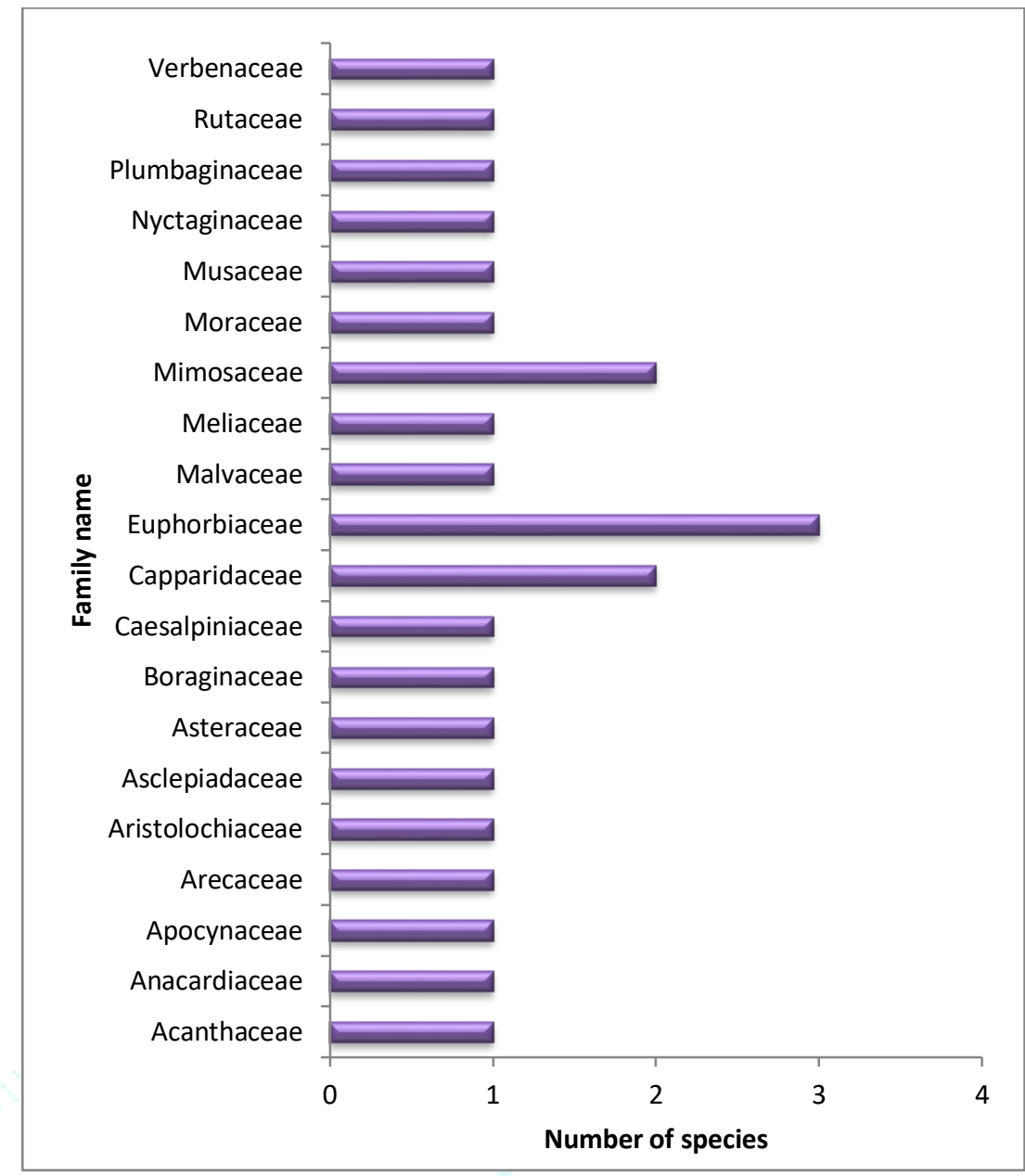

Figure 1: Families with number of species

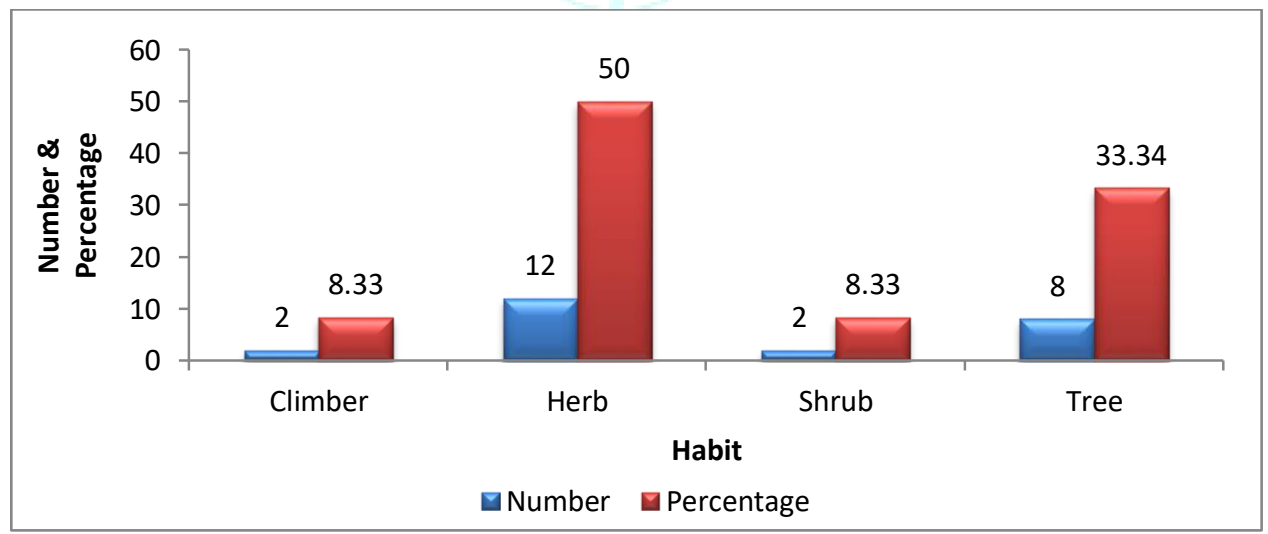

Figure 2: Number and percentage of plants in various habits

The results also shows that leaves (50.0\%) were the preferable plant part used to treat skin infections, followed by root and stem (11.54\% each) (Fig 3). In most other ethnobotanical studies where plants are used to treat various disorders, the leaves are also the preferable plant part used 10-17. It was also noted the recorded plant species were prepared in a variety of ways. The plant materials were used as fresh in the preparation of paste $(61.54 \%)$, extract (11.54\%), latex (11.54\%), juice (7.7\%), exudate (3.84\%) and oil (3.84\%) (Fig 4). Administration of the different plant parts were mostly $(84.62 \%)$ applied topically as a paste (Fig 5). The most common treatments in other similar survey conducted in nearby district of present stud area is also confirmed that the use of medicines as pastes in the treatment of skin diseases 18 .

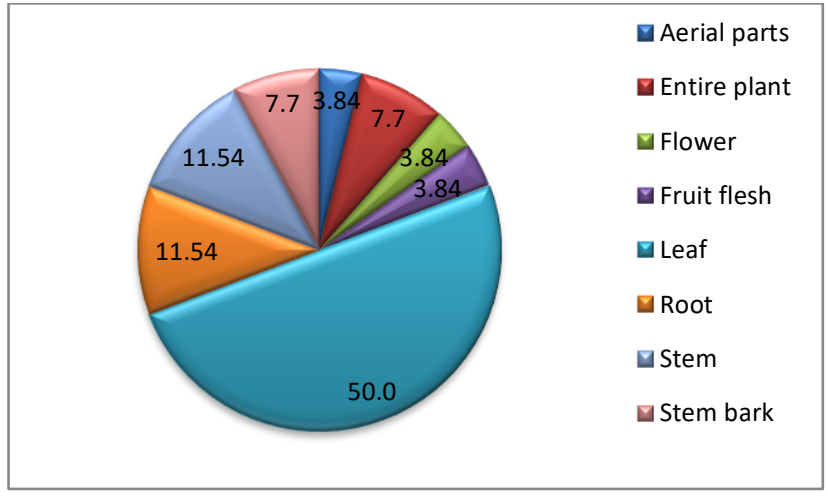

Figure 3: Percentage of plant parts used 


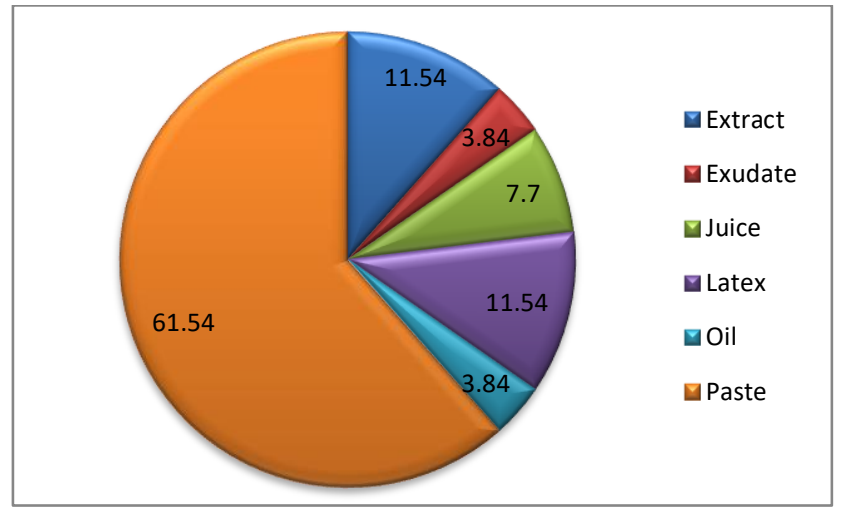

Figure 4: Percentage of mode of medicinal preparation

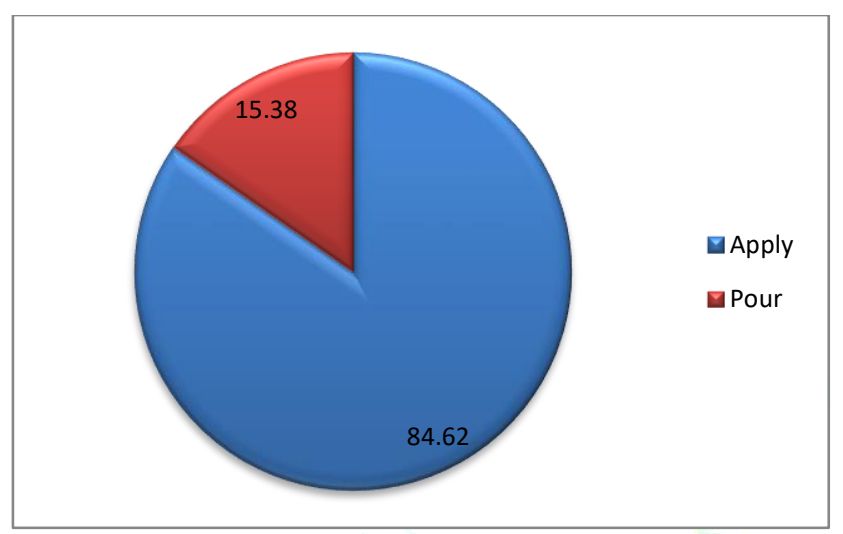

Figure 5: Percentage of mode of medicinal application

The informants mentioned 16 different skin diseases which are treated with different plant-based medication (Fig 6). Among the plants recorded, 6 plants were used to heal wound, 4 plants each to treat burn and cut, 3 plants were prescribed in the treatment of boil and eczema, 2 plants to heal heel crack and each of single species to remaining ailments (Fig 6).

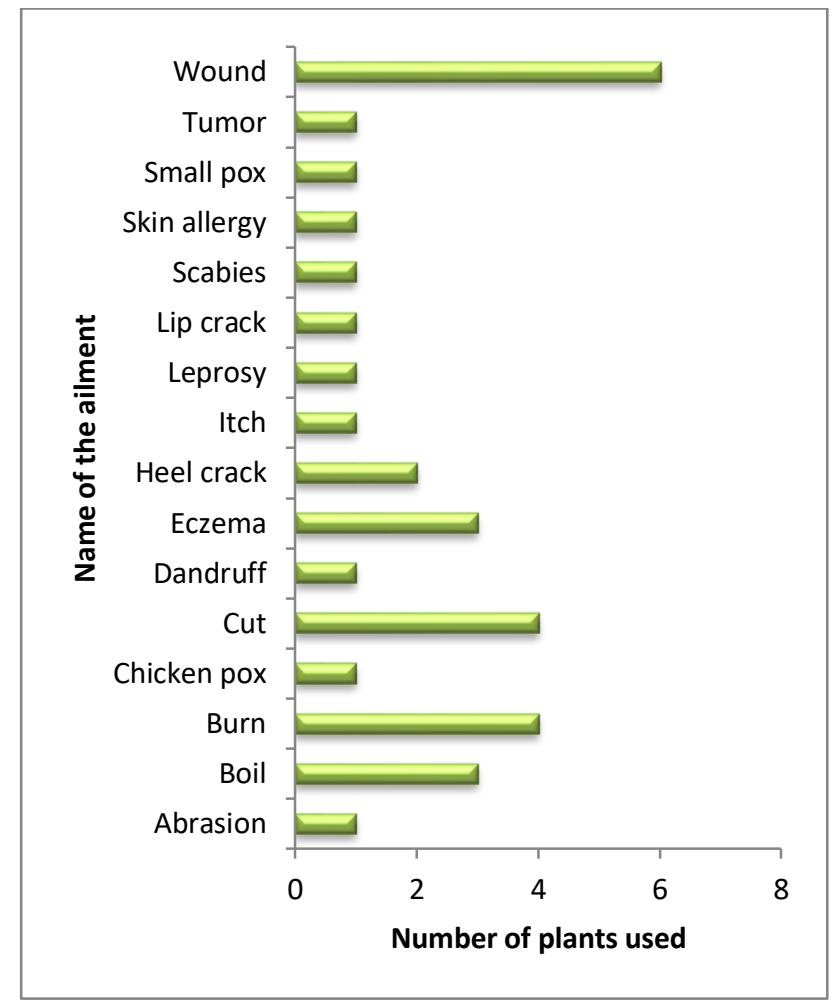

Figure 6: Number of plants used for each skin ailment
It was reported that two common skin disorders are wounds and burns which are likely to happen in rural communities where wood is mostly used as fuel for cooking. A recent survey done in the north eastern state of India revealed that 46 plant species are used exclusively to treat various dermatological problems including wound 3 . Various other studies globally have also reported plant remedies for the treatment of wounds 5,19-21. The present study is not corresponding with a study done in Kenya ${ }^{22}$, where sores are the most frequently treated skin disease.

\section{CONCLUSION}

Further studies should be carried out to validate the possible antimicrobial efficacies of these plants against skin relevant pathogens. Additional ethnobotanical survey should be conducted to explore the whole traditional knowledge of rural dwellers of the study area on plants used for the treatment other ailments. Conservation strategies should be carried out on these medicinally important species.

\section{ACKNOWLEDGEMENT}

The authors are grateful to the informants of Arasankulam and Kottarakurichi of Thoothukudi district for their contribution during study.

\section{CONFLICT OF INTEREST}

The authors have declared that there is no conflict of interest.

\section{REFERENCES}

1. Abbasi AM, Khan MA, Ahmad M, Zafar M, Jahan S \& Sultana S. Ethnopharmacological application of medicinal plants to cure skin diseases and in folk cosmetics among the tribal communities of North-West Frontier Province, Pakistan. Journal of Ethnopharmacology, 2010; 128:322-335.

2. Quave CL, Pieroni A \& Bennett BC. Dermatological remedies in the traditional pharmacopoeia of Vulture-Alto Bradano, inland southern Italy. Journal of Ethnobiology \& Ethnomedicine, 2008: 4:5. doi:10.1186/1746-4269-4-5.

3. Sharma KK, Kotoky J, Kalita JC \& Sarma GC. Traditional use of medicinal plants for anti-ringworm therapy in some parts of Kamrup District of Assam, a North Eastern State of India. Andhra Pradesh Journal of Psychological Medicines, 2012: S316-S319.

4. Agyare C, Asase A, Lichtenberg M, Niehues M, Deters A \& Hensel A. An ethnopharmacological survey and in vitro confirmation of ethnopharmacological use of medicinal plants used for wound healing in Bosomtwi-Atwima-Kwanwoma area, Ghana. Journal of Ethnopharmacology, 2009; 125:393-403.

5. Adetutu A, Witson AM \& Corcoran O. Ethnopharmacological survey and in vitro evaluation of wound-healing plants used in South-western Nigeria. Journal of Ethnopharmacology, 2011; 137:50-56

6. Gul F, Shinwari ZK \& Afzal I. Screening of indigenous knowledge of herbal remedies for skin diseases among local communities of North West Punjab, Pakistan. Pakistan Journal of Botany, 2012; 5:1609-1616.

7. Saikia AP, Ryakala VK, Sharma P, Goswami P \& Bora U. Ethnobotany of medicinal plants used by Assamese people for various skin ailments and cosmetics. Journal of Ethnopharmacology, 2006; 106:149-157.

8. Gamble JS \& Fischer CEC. The Flora of the Presidency of Madras (Reprint Edited), Vols. I - III. Botanical survey of India, Calcutta, India, 1957.

9. Matthew KM. An Excursion Flora of Central Tamil Nadu. Oxford and IBH Publishing Co. Pvt. Ltd., New Delhi, India, 1991.

10. Shanmugam S, Rajagopal V \& Rajendran K. Multipurpose usable plants in Thalaiyanai hills of Tirunelveli forest division in southern part of Western Ghats. Journal of Non-Timber Forest Products, 2007; 14(4):297-306.

11. Shanmugam S, Ramar S, Ragavendhar K, Ramanathan R \& Rajendran K. Plants used as medicine by Paliyar tribes of Shenbagathope in Virudhunagar district of Tamil Nadu. Journal of Economic and Taxonomic Botany, 2008; 32(4):922-929. 
12. Shanmugam S, Manikandan K \& Rajendran K. Ethnomedicinal survey of medicinal plants used for the treatment of diabetes and jaundice among the villagers of Sivagangai district, Tamil Nadu. Ethnobotanical Leaflets, 2009; 13: 186-193.

13. Shanmugam S, Annadurai M \& Rajendran K. Ethnomedicinal plants used to cure diarrhea and dysentery in Pachalur hills of Dindigul district in Tamil Nadu, Southern India. Journal of Applied Pharmaceutical Sciences, 2011a; 1(8):94-97.

14. Shanmugam S, Kalaisevan $M$, Selvakumar $P$, Suresh K \& Rajendran K. Ethnomedicinal pants used to cure diarrhea and dysentery in Sivagangai district of Tami Nadu, India. International Journal of Research in Ayurveda and Pharmacy, 2011b; 2(3):991-994.

15. Shanmugam S, Rajendran K \& Suresh K. Traditional uses of medicinal plants among the rural people in Sivagangai district of Tamil Nadu, Southern India. Asian Pacific Journal of Tropical Biomedicine, 2012a; 2:S429-S434.

16. Shanmugam $S$, Balamurugan $S$, Pandiselvam $P$ \& Rajendran K. Medicinal plants used by the people of Thiruppuvanam and its surrounding areas of Sivagangai district in Tamil Nadu, Southern India. Journal of Basic and Applied Biology, 2012b; 6:39-45.

17. Shanmugam S, Jeyaprabakaran G \& Rajendran K. Medicinal trees from home gardens of urban areas in Madurai district of Tamil
Nadu, Southern India. Asian Journal of Ethnobiology, 2020; 3(1):10-15.

18. Chendurpandy P, Mohan VR \& Kalidass C. An ethnobotanical survey of medicinal plants used by the Kanikkar tribe of Kanyakumari district of Western Ghats, Tamil Nadu for the treatment of skin diseases. Journal of Herbal Medicine and Toxicology, 2020; 4(1):179-190.

19. Inngjerdingen K, Nergård CS, Diallo D, Mounkoro PP \& Paulsen BS. An ethnopharmacological survey of plants used for wound healing in Dogonland, Mali, West Africa. Journal of Ethnopharmacology, 2004; 92:233-244.

20. Martínez GJ \& Barboza GE. Natural pharmacopoeia used in traditional Toba medicine for the treatment of parasitosis and skin disorders (Central Chaco, Argentina). Journal of Ethnopharmacology, 2010; 132:86-100.

21. Dey A, Gupta B \& De JN. Traditional phytotherapy against skin diseases and in wound healing of the tribes of Purulia district, West Bengal, India. Journal of Medicinal Plants Research, 2012; 33:4825-4831.

22. Njoroge GN \& Bussmann RW. Ethnotherapeutic management of skin diseases among the Kikuyus of Central Kenya. Journal of Ethnopharmacology, 2007; 111:303-307. 